\title{
Improvement of Multifunctional Automotive Textile
}

\author{
Zeynep Ömeroğulları Başyiğit \\ Uşak University, Faculty of Engineering, Textile Engineering Department, Uşak, Turkey
}

Corresponding Author: Zeynep Ömeroğulları Başyiğit, zeynep.omerogullari@usak.edu.tr

\begin{abstract}
In order to improve multifunctional automotive textile, required functionalities that have been expected by the automotive industry were enhanced in this study. For this aim, flame retardant and water-oil repellent effects were achieved on $100 \%$ polyester based automotive fabrics via pad-dry-cure system with performed finishing recipes. After functionalization of the fabrics, polyurethane based foams were laminated to the treated automotive textiles. In order to be able to compare the results of tests and to determine the effects of used chemicals on the functionalities of fabrics, chemical amounts of recipe were optimized and the results were discussed. Flame retardancy, water repellency and oil repellency tests were performed before and after abrasion tests. Color spectrums of treated fabrics were tested after chemical finishing applications. Morphological analyses of samples were tested by SEM and chemical structures of the fabrics were analyzed by FTIR-ATR. According to performance test results, multifunctional automotive textile including flame retardant and water-oil repellent effect was achieved successfully. During the burning test, it was determined that laminated textile structure was selfextinguished whereas $3 \mathrm{M}$ water repellency grades were at the highest value before abrasion tests.
\end{abstract}

\section{ARTICLE HISTORY}

Received: 28.10.2018

Accepted: 27.03 .2019

\section{KEYWORDS}

Automotive textile, flame retardant, water-oil repellent, chemical finishing application

\section{INTRODUCTION}

Automotive textiles have one of the most valuable world markets for technical textiles and there is a broad spectrum of products comprising novel textile structures and high quality design. Automotive technical textiles include wide range of materials such as upholstery and seating, floor covering trunk liners, headliners door and side-panel coverings, pillar coverings as well as safety belts, airbags, thermal and sound insulators, tyres and textile-reinforced flexible and hard composites. The textiles for interior furnishings are primarily made of woven, warp knitted, weft knitted, laminated fabrics and nonwovens [1-3].

The requirements for textile structures used in automotives are different from those used in clothing and other applications. The performance of the automotive textiles, which constitute approximately $20-25 \mathrm{~kg}$ in a car, depends on the fibre properties, fabric structures and various finishes used in the manufacturing processes [4-6]. Car seat fabric requires considerable technical input to produce both the aesthetic and also very demanding requirements such as reduced flammability, abrasion resistance, resistance to sunlight, soil resistance and UV degradation [2,7]. Since seat covers cannot be washed in washing machine, these must show strong soil masking behavior $[1,8]$. The design and performance properties of technical textiles present in automotive interiors are among the most important criteria for consumer satisfaction and this design and performance criteria could be varied according to consumer's requirement $[1,2]$.

Automobile seat upholstery generally includes multicomponent structures. The seat covering is composed of foam cushion mostly made up of polyurethane, for the seat back and bottom and a trim component including a face material, predominantly a polyester fabric, foam backing, mostly made up of polyurethane and a reinforcing scrim

To cite this article: Ömeroğulları Başyiğit, Z. 2019. Improvement of multifunctional automotive textile. Tekstil ve Konfeksiyon. 29(2), 113-120. 
material, generally polyamide knitted fabric. On the top surface, weaved or knitted textile fabric can be used as well $[3,9]$. Polyurethane based foams which exist under the top surface layer, are laminated to the fabric in various ways [3, 10-15]. Laminated polyurethane foams provide comfortable feeling and prevent the wrinkling of the top surface. Usually the bottom layer of the assembly is furnished with a knitted, nonwoven, or film backing, to impart dimensional stability and prevent excessive foam wear. Over many years, these layers have been combined on a large scale by flame lamination (Fig.1), since ample production rates and low cost have ensured good returns to processors $[16,17]$.

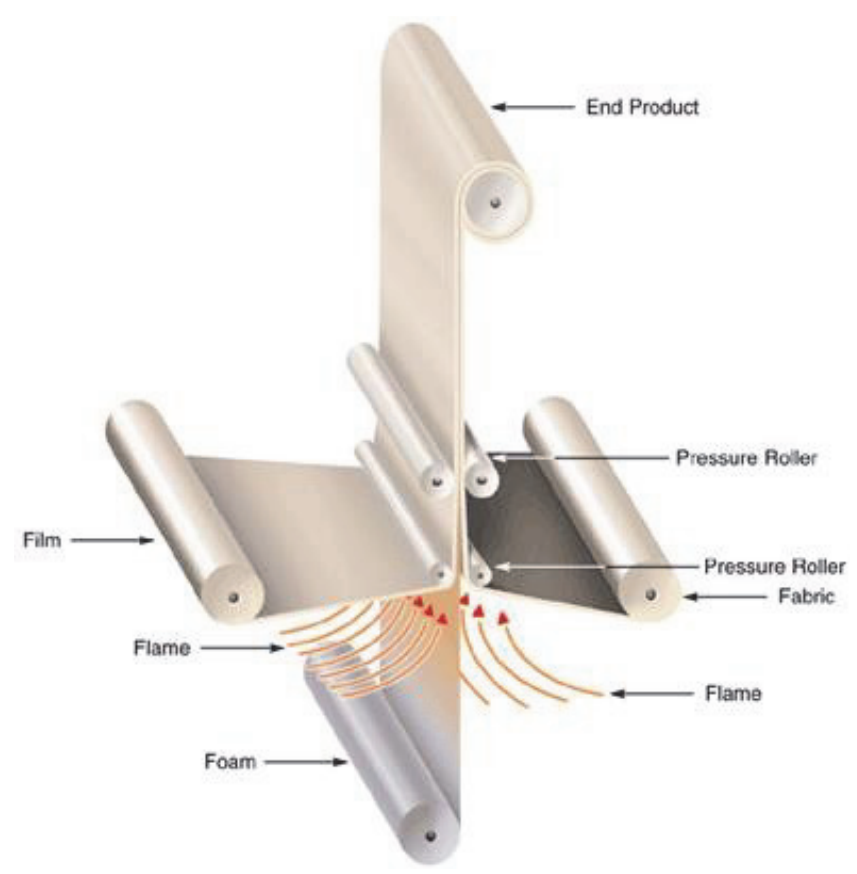

Figure 1. Flame lamination [10]

In flame lamination, a layer of foam is exposed to an open flame at around $950 \quad \mathrm{C}$ which causes its uppermost surface to melt. While the foam is molten, it is fed into an arrangement of nip rollers which presses an incoming layer of fabric onto its surface, as depicted in Fig. 1. When the laminate has cooled, strong chemical bonds develop between the adjacent layers $[3,10,12,16]$.

For the upholstery fabrics with improved functional characteristics, the selection of the top surface fabric is important as well as the selection of functionalities that are to be applied on. The volume of upholstery fabric used per vehicle varies by region however an average $5-6 \mathrm{~m}^{2}$ of fabric are used in cars for upholstery [6]. It should be also emphasized that warp-knitting sector has broadened its market base and especially has expanded into automotive industry [1-3]. Due to its significant mechanical performance, polyester has been established as the most popular fibre for automotive textiles. On the whole, polyester fibre provides good mechanical performance including good abrasion resistance, high dimensional stability, excellent resistance to photo-oxidative degradation, and high light fastness [16].
Nowadays, when compared to mono-functional textiles, the request for multifunctional textile materials has been increased especially in the automotive textile industry. Since the goal of the finishing operations undertaken by upholstery manufacturers is the same "to bestow fabrics with particular aesthetic and functional qualities", multifunctional automotive textile was improved in this study. Flame retardant and water-oil repellent effects were achieved on $100 \%$ polyester based automotive upholstery fabrics via pad-dry-cure system with performed finishing recipes. After functionalization of the fabrics, polyurethane based foams were laminated to the treated automotive fabrics. According to the performance tests results, flame retardant and wateroil repellent effect was achieved successfully and it was determined that laminated textile structure showed selfextinguishing behavior whereas $3 \mathrm{M}$ water repellency grades were at the highest value before abrasion tests.

\section{EXPERIMENTAL DETAILS}

\subsection{Material}

$100 \%$ polyester double-face knitted fabrics with two different densities ( 36 wales x 22 courses, $50 \mathrm{~g} / \mathrm{m}^{2}$ ) and $(28$ wales $x$ 22 courses, $40 \mathrm{~g} / \mathrm{m}^{2}$ ) and polyurethane based foams (density with $32 \mathrm{~g} / \mathrm{m}^{3}$ ) were supplied by Martur Company (Turkey). Polyethylene based softener was taken from Tanatex (Turkey) and fluoroalkyl acrylate copolymer was gently supplied by Daikin America, NY, USA while nitrogen containing phosphonic acid salt as a flame retardant agent and Invadine PBN as an anionic surfactant were purchased from Huntsman Textile Effects (Charlotte, USA). $\mathrm{CaCO}_{3}$ based non-durable flame retardant agent was gently supplied by Kale Natural and anionic surfactant was added into the finishing bath as a wetting agent.

\subsection{Method}

$100 \%$ polyester double-face knitted fabrics with two different densities were used in this study. Both fabrics were generally used as transportation upholstery fabrics in the textile market. The dyeing procedure was carried out with disperse dyestuff Foron Black AS-3LF in HT conditions. Two chemical finishing recipes were used in pad-dry-cure system (Mathis VFM, vertical padder and Mathis oven PTE-B) for this study in order to optimize the amounts and to determine the effects of chemical agents on the functionalities of the textile structures. In order to improve the flame retardancy and water-oil repellency effect of upholstery fabrics, $200 \mathrm{~g} / \mathrm{L}$ nitrogen containing phosphonic acid salt, $5 \mathrm{~g} / \mathrm{L}$ anionic surfactant, $20 \mathrm{~g} / \mathrm{L}$ polyethylene based softener and $80 \mathrm{~g} / \mathrm{L}$ fluoroalkyl acrylate copolymer were used in both recipes of finishing process. In recipe 1 , while $125 \mathrm{~g} / \mathrm{L} \mathrm{CaCO}_{3}$ based chemical solution was added into the bath, in the second recipe, this amount was used as $200 \mathrm{~g} / \mathrm{L}$. After applying all primary and auxiliary chemicals in padding bath with a wet pick- up ratio as $85 \%$, the fabrics were dried at $11^{\circ} \mathrm{C}$ for $1-2$ min, and then cured at $145{ }^{\circ} \mathrm{C}$ for $2 \mathrm{~min}$. The knitted polyester fabrics which had multifunctional finishing application were laminated with polyurethane foams in flame laminator (Mario Crosta). All fabrics were laminated with flame lamination method in speed of $30 \mathrm{~m} / \mathrm{min}$. Codes of treated fabrics were shown in Table 1 below. 
Table 1. Codes of samples

\begin{tabular}{ll}
\hline Codes of samples & Explanation \\
\hline UF1 & Untreated $50 \mathrm{~g} / \mathrm{m}^{2}$ polyester fabric \\
UF2 & Untreated $40 \mathrm{~g} / \mathrm{m}^{2}$ polyester fabric \\
F1A & $50 \mathrm{~g} / \mathrm{m}^{2}$ polyester fabric that treated with recipe 1 \\
F2A & $40 \mathrm{~g} / \mathrm{m}^{2}$ polyester fabric that treated with recipe 1 \\
F1B & $50 \mathrm{~g} / \mathrm{m}^{2}$ polyester fabric that treated with recipe 2 \\
F2B & $40 \mathrm{~g} / \mathrm{m}^{2}$ polyester fabric that treated with recipe 2 \\
LF1A & Laminated textile composite material that included $50 \mathrm{~g} / \mathrm{m}^{2}$ polyester fabric which treated with recipe 1 \\
LF2A & Laminated textile composite material that included $40 \mathrm{~g} / \mathrm{m}^{2}$ polyester fabric which treated with recipe 1 \\
LF1B & Laminated textile composite material that included $50 \mathrm{~g} / \mathrm{m}^{2}$ polyester fabric which treated with recipe 2 \\
LF2B & Laminated textile composite material that included $40 \mathrm{~g} / \mathrm{m}^{2}$ polyester fabric which treated with recipe 2 \\
\hline
\end{tabular}

\subsection{Flame Retardancy Test (ISO 3795)}

Flame retardant effects of samples were tested according to ISO 3795. This test was used for determining the horizontal burning rate of textile composite structures used in the road vehicles (for example, passenger cars, lorries/trucks, estate cars, coaches), and of tractors and machinery for agriculture and forestry [18]. The sample, held horizontally in a Ushaped holder, was exposed to the flame for $15 \mathrm{~s}$ in a combustion chamber as showed in Fig. 2. The test determined if and when the flame extinguished or the time in which the flame passed a measured distance.

$$
\mathrm{B}=60 \times(\mathrm{D} / \mathrm{T})
$$

where, $B$ is the burn rate in millimeters per minute, $D$ the length the flame travels in millimeters and $T$ the time in seconds for the flame to travel $\mathrm{D}$ millimeters.

\subsection{M Water Repellency Test Method}

Water repellent effects of samples were tested according to $3 \mathrm{M}$ Water Repellency Test Method. According to $3 \mathrm{M}$ water repellency test method the samples were placed flat on a smooth, horizontal surface. 3 small droplets which consisted of water/alcohol were placed onto the sample using a pipette. The droplets were observed for $10 \mathrm{~s}$. When after 10 $\mathrm{s}, 2$ of the 3 droplets were still visible as spherical to hemispherical, the fabric passed the test. Samples were rated as pass or fail of the appropriate test liquid, $W-10$. Standard test liquids using in this test were shown in Table 2 [19].

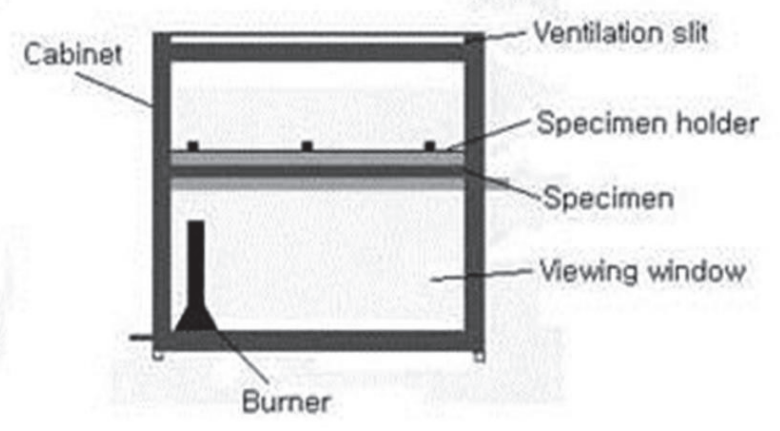

Figure 2. Standard of ISO 3795 [18]

Table 2. Standard test liquids for $3 \mathrm{M}$ water repellency test method

\begin{tabular}{cc}
\hline 3M Water Repellency Rating Number & Composition of Test Liquid \\
\hline W & Water \\
1 & $90 / 10$ Water/2-Propanol \\
2 & $80 / 20$ Water/2-Propanol \\
3 & $70 / 30$ Water/2-Propanol \\
4 & $60 / 40$ Water/2-Propanol \\
5 & $50 / 50$ Water/2-Propanol \\
6 & $40 / 60$ Water/2-Propanol \\
7 & $30 / 70$ Water/2-Propanol \\
8 & $20 / 80$ Water/2-Propanol \\
9 & $10 / 90$ Water/2-Propanol \\
10 & 2-Propanol \\
\hline
\end{tabular}




\subsection{M Oil-Repellency Test Method}

Oil repellent effects of samples were tested according to $3 \mathrm{M}$ Oil Repellency Test Method. According to $3 \mathrm{M}$ oil repellency test methods, the samples were placed flat on a smooth, horizontal surface. Small droplets were placed onto the sample using a pipette. The droplets were observed for $30 \mathrm{~s}$ from a $45^{\circ}$ angle. When the droplet neither wetted the fabric, nor had any sign of wicking, the test was repeated using the next numbered oil. This was continued until an oil sample was found to either wet the fabric or show wicking. The oil repellency rating was deemed to be the highest numbered test oil which did not wet the fabric within $30 \mathrm{~s}$. Standard test liquids for this test were shown in Table 3 [19].

Table 3. Standard test liquids for $3 \mathrm{M}$ oil repellency test method

\begin{tabular}{cc}
\hline $\begin{array}{c}\text { 3M oil repellency } \\
\text { rating number }\end{array}$ & Composition of test liquid \\
\hline 1 & Liquid paraffin \\
2 & 65/35 liquid paraffin /n-hexadecane \\
3 & n-hexadecane \\
4 & n-tetradecane \\
5 & n-dodecane \\
6 & n-decane \\
7 & n-octane \\
8 & n-heptane \\
\hline
\end{tabular}

\subsection{Color Spectrum Analysis}

CIE $L^{*}, a^{*}, b^{*}$ and $\Delta E$ values of untreated and treated polyester fabrics were investigated by GretagMacbeth-7000 A Spectrophotometer.

\subsection{Scanning Electron Microscope (SEM) Test}

The surface morphology of untreated and treated polyester fabrics were scanned by a ZEISS/EVO 40 electron microscope at $10 \mathrm{kV}$ under a high vacuum at $\times 1500$ magnification after being coated with gold-palladium (Au-PI) at a thickness of $40-50 \mathrm{~nm}$ by a BAL-TEC SCD 005 coating device.

\subsection{Fourier Transform Infrared (Attenuated Total Reflectance) Spectra FTIR-ATR analysis}

FT-IR ATR spectra of the untreated and treated polyester fabrics were investigated by a Thermo Nicolet 6700 device in a wave number range of $525-4000 \mathrm{~cm}^{-1}$.

\section{RESULTS AND DISCUSSION}

\subsection{Flame Retardancy Tests Results (ISO 3795)}

Burning rates of laminated textile composite materials were shown in Fig. 3 according to standard of ISO 3795. As it was seen below, flame retardant effect of the composite was increased significantly while untreated textile composite structure was burned totally with the burning rate of 156 $\mathrm{mm} / \mathrm{min}$. It should be noted here that automotive industries generally uses market chemicals in one-step finishing process in order to achieve multifunctional upholstery fabric such as flame retardant and water-oil repellent at the same time but they reported from their laboratory studies that when fluorocarbon based chemicals were added into phosphonic acid salt baths, the burning rate of the textile composites was over $100 \mathrm{~mm} / \mathrm{min}$ which could not be accepted by the car producers. So here in this study, it was considered that increasing the amount of phosphonic acid salt in the bath would not make a positive change on FR effect when using fluorocarbon based chemicals in the same bath in one-step finishing processes. That's why; calcium carbonate based FR agent was added into the bath in order to determine the burning behavior of textile composites. As it was shown in Fig. 3, the burning rates of treated textile composites decreased significantly when compared to untreated ones. It was considered that endothermic decomposition reactions of calcium carbonate provided heat sink on the fibers that combustion was retarded [20,21]. This flame retardant effect was more significant when the amount of calcium carbonate based chemical was increased. If the treated textile composites were compared to each other, it could be clearly seen that LF1A and LF1B had better flame retardant effect than LF2A and LF2B which was contributed to the effect of density properties on burning behavior of fabrics. It was observed that when the density of the fabric was increased, flame retardant effect was improved because of decreasing the air gaps between the yarns which were responsible for carrying oxygen that caused inflammation.

\subsection{M Water and Oil Repellency Test Results}

$3 \mathrm{M}$ water and oil repellency test results of were shown in Table 4 and Table 5, respectively. As seen in Table 4, water repellency grades were at the highest rate or around 10 whereas the oil repellency rates were around 6-5. It was considered that fluoroalkyl acrylate copolymer provided excellent water repellent effect and good oil repellent effect on polyester fabrics whereas untreated samples did not show any water or oil repellent effect. When the amount of calcium carbonate was increased, it was indicated that water repellency effect decreased slightly. This result was attributed to the water absorption effect of calcium carbonate that showed either when used in composite materials [22] or used in finishing bath of textile materials such as polyester and cotton [23,24]. However, after 20000 cycle abrasion tests, both water and oil repellency rates were decreased. It was considered that these results were obtained because of abrasion and removing of non-durable finishing agents on the surface of the fibers with the friction movement of the load used in abrasion test device. 


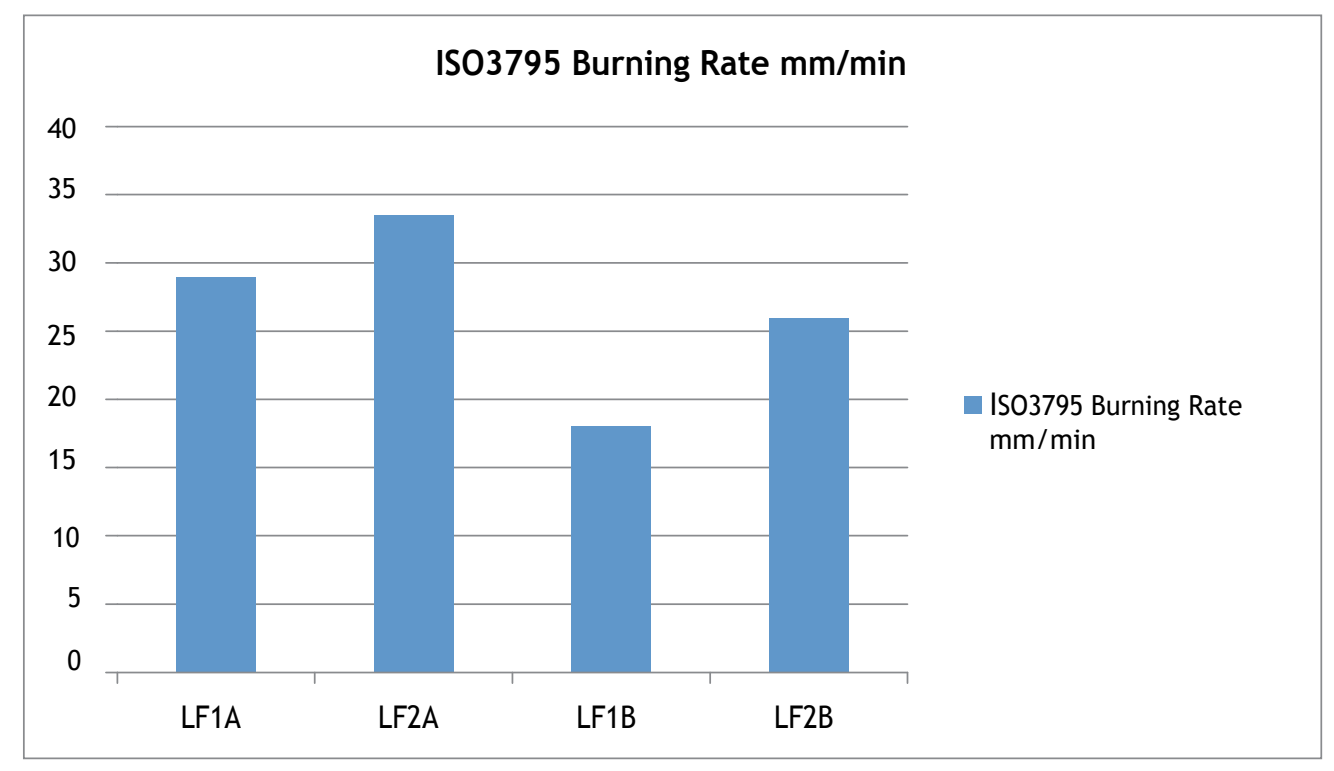

Figure 3. Burning rates of laminated textile composites after finishing process

Table 4. 3M water repellency test results

\begin{tabular}{ccc}
\hline Samples & 3M water repellency test grades & After abrasion test (Martindale) 20000 cycle \\
\hline F1A & 10.5 & 7 \\
F2A & 10 & 6 \\
F1B & 10 & 6.5 \\
F2B & 9.5 & 5 \\
\hline
\end{tabular}

Table 5. 3M oil repellency test results

\begin{tabular}{ccc}
\hline Samples & 3M oil repellency test grades & After abrasion test (Martindale) 20000 cycle \\
\hline F1A & 6.5 & 5.5 \\
F2A & 5 & 4.5 \\
F1B & 6.5 & 5.5 \\
F2B & 5.5 & 4 \\
\hline
\end{tabular}

\subsection{Color Spectrum Analysis Results}

Color spectrum analysis of treated polyester fabrics were shown in Table 6 and Table 7. It was determined according to the color spectrum results that, $\Delta \mathrm{E}$ values of all treated fabrics were around 1.00 which considered as these finishing applications did not cause significant color changes on knitted polyester fabrics. For both color spectrum analysis results (Table 6 and Table 7), it was indicated that when the amount of $\mathrm{CaCO}_{3}$ was increased in the recipe, $\Delta \mathrm{E}$ values increased slightly. For the first recipe, it was concluded that $\Delta \mathrm{E}$ values did not even reach 1.00 after application of both polyester fabrics.

Table 6. Color spectrum analysis of F1A and F1B

\begin{tabular}{lllll}
\hline Samples & \multicolumn{5}{c}{ CIE L* $\mathbf{a}^{*} \mathbf{b}^{*}$ Values } \\
\hline & $\mathbf{L}^{*}$ & $\mathbf{a}^{*}$ & $\mathbf{b}^{*}$ & $\Delta \mathbf{E}$ \\
\cline { 2 - 5 } UF1 & 17.15 & 0.13 & -0.38 & - \\
F1B & 15.92 & 0.13 & -0.09 & 1.22 \\
F1A & 16.44 & 0.13 & -0.14 & 0.75 \\
\hline
\end{tabular}

Table 7. Color spectrum analysis of F2A and F2B

\begin{tabular}{|c|c|c|c|c|}
\hline \multirow[t]{2}{*}{ Samples } & \multicolumn{3}{|c|}{ CIE L* $a^{*} b^{*}$ Values } & \multirow[b]{2}{*}{$\Delta \mathbf{E}$} \\
\hline & $L^{*}$ & $a^{*}$ & $\mathbf{b}^{*}$ & \\
\hline UF2 & 18.35 & 0.11 & -0.49 & - \\
\hline F2B & 17.41 & 0.16 & -0.13 & 1.00 \\
\hline F2A & 17.35 & 0.09 & -0.24 & 0.96 \\
\hline
\end{tabular}




\subsection{Scanning Electron Microscope (SEM) Results}

SEM micrographs at $\times 1500$ magnification of untreated polyester fabrics and fabrics treated with recipe 1 , were shown in Fig. 4. In order to observe the chemical particles easily in the micrographs, polyester fabrics treated with recipe 2 which had increased amount of FR agent, was selected for microscope analysis. According to the SEM results, it was determined that clean and smooth surfaces were seen in Figs. $4 \mathrm{a}$ and $4 \mathrm{c}$ whereas some chemical particles and residues were indicated on the polyester yarn surfaces after finishing applications as shown in Figs. $4 \mathrm{~b}$ and $4 \mathrm{~d}$.

\subsection{Fourier Transform Infrared (Attenuated Total Reflectance) Spectra FTIR-ATR Analysis Results}

FTIR-ATR analysis of untreated $50 \mathrm{~g} / \mathrm{m}^{2}$ polyester fabric (UF1) and $50 \mathrm{~g} / \mathrm{m}^{2}$ polyester fabric that treated with recipe 2 (F1B) were shown in Fig. 5. Here, in order to be able to capture the certain peaks in this analysis, recipe 2 which was consisted of most increased amount of chemical agents, was selected. This figure indicated the characteristic peaks of the polyester which were seen at $1715 \mathrm{~cm}^{-1}$ (carbonyl $\mathrm{C}=\mathrm{O}$ tension vibration), $1242 \mathrm{~cm}^{-1}$ (aromatic ester $\mathrm{C}-\mathrm{C}-\mathrm{O}$ tension vibration) and $1096 \mathrm{~cm}^{-1}$ (aromatic ester O$\mathrm{C}-\mathrm{C}$ tension vibration) [23]. Figure 5 also gave the detail about bonding of phosphonic acid salt based flame retardant agent to the polyester fabric. In the spectra of FB1, since the wave number range of the $\mathrm{P}-\mathrm{O}-\mathrm{R}$ vibration was generally seen between the range of $1100-950 \mathrm{~cm}^{-1}$, an interaction of flame retardant agent with the polyester fabric could be observed at $1056 \mathrm{~cm}^{-1}$ which occurred a vibration differently from untreated fabric. Additionally, the peak of the $\mathrm{P}=\mathrm{O}$ vibration could be indicated between the range of $1350-1150 \mathrm{~cm}^{-1}$ [25] for the treated fabric which could be attributed to phosphonic acid salt based FR agent that was used in this study. When the calcium carbonate based FR agent was investigated in the spectra, it could be mentioned that any characteristic peaks of $\mathrm{CaCO}_{3}$ could be seen in the spectra expect the vibrations occurred around the range of water peaks of substances, $3200-2800 \mathrm{~cm}^{-1}$ which was considered as it was occurred because of the water absorption characteristic of calcium carbonate based FR agent [26]. a). UF1
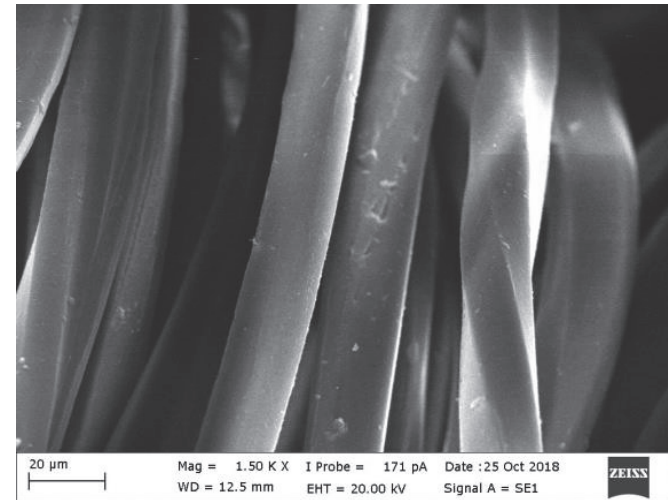

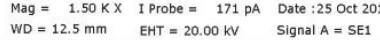
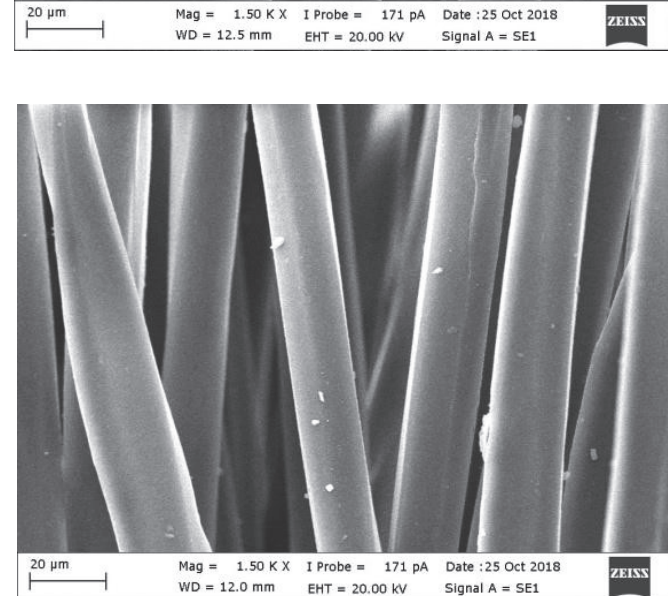

c). UF2

Mag $=1.50 \mathrm{KX} \quad \mathrm{I}$ Probe $=171$ pA Date $: 25$ oct 2010

d). $F 2 B$

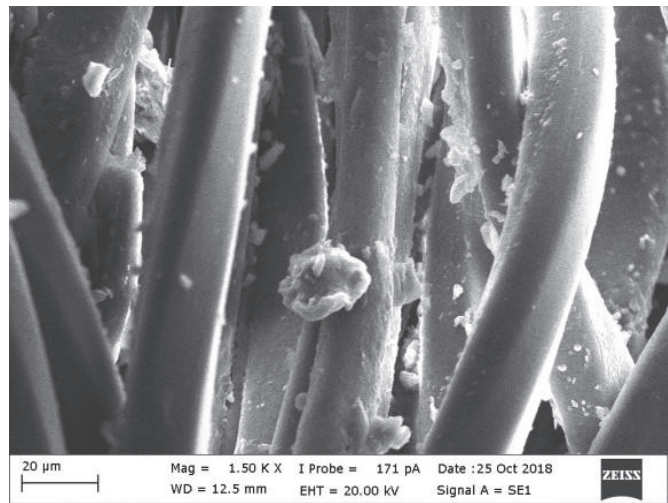

b). F1B

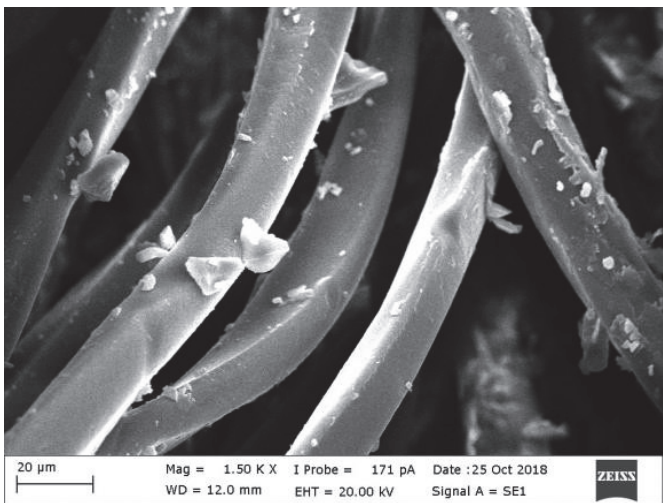

Figure 4. SEM results of a) untreated $50 \mathrm{~g} / \mathrm{m}^{2}$ polyester fabric b) $50 \mathrm{~g} / \mathrm{m}^{2}$ polyester fabric that treated with recipe $2 \mathrm{c}$ ) untreated $40 \mathrm{~g} / \mathrm{m}^{2}$ polyester fabric d) $40 \mathrm{~g} / \mathrm{m}^{2}$ polyester fabric that treated with recipe 2 


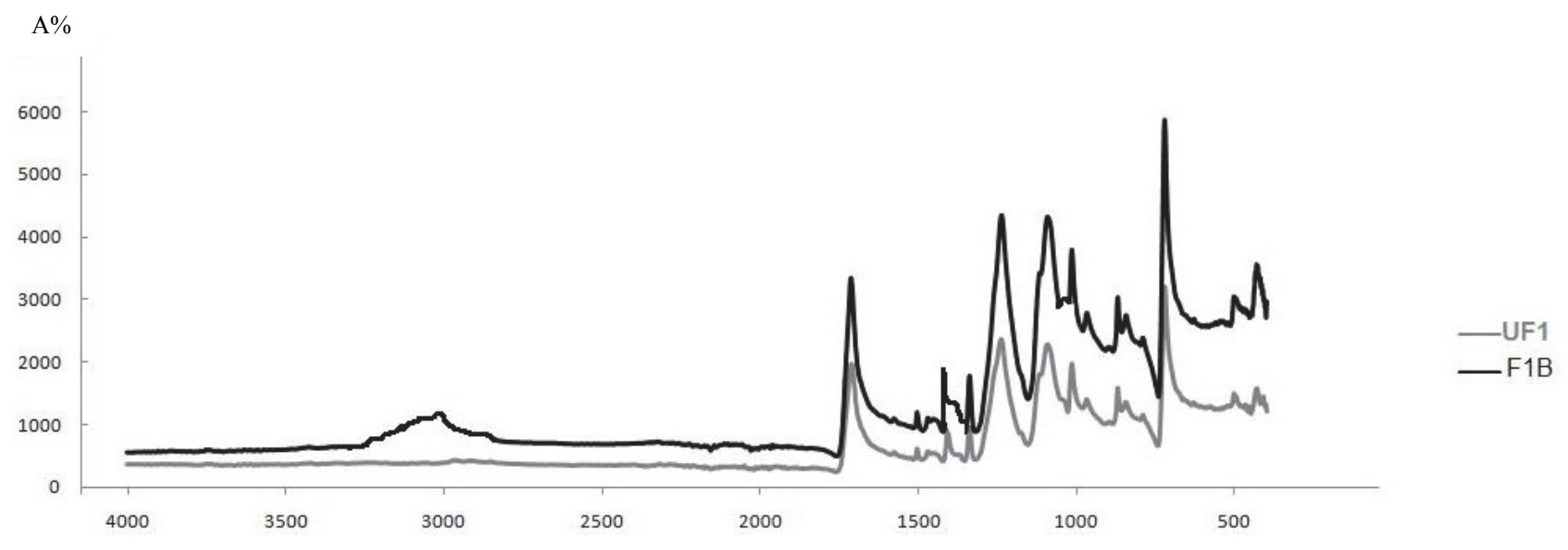

Figure 5. FTIR-ATR analysis results of UF1 and F1B

\section{CONCLUSION}

Since the request for multifunctional textile materials was increased especially in the automotive textile industry, in this study flame retardant and water-oil repellent automotive textiles were improved to fulfill this demand of industry. For this aim $100 \%$ polyester knitted automotive fabrics applied with flame retardant and water-oil repellent agents in paddry-cure system with performed finishing recipes. After functionalization of the fabrics, polyurethane based foams were laminated to the treated automotive textiles. According to the flame retardancy test (ISO 3795), the flame retardant effect of laminated textile composites were increased significantly. Burning rates of them were in the range 19$33.5 \mathrm{~mm} / \mathrm{min}$. It was concluded that flame retardant effect was more significant when the amount of calcium carbonate based chemical was increased in the finishing recipe. When the treated textile composites were also compared to each other, it was determined that LF1A and LF1B had better flame retardant effect than LF2A and LF2B which was

\section{REFERENCES}

1. Shishoo, R. (Ed.). (2008). Textile advances in the automotive industry Elsevier.

2. Fung, W. (2000). Textiles in transportation. Handbook of technical textiles, 490-528.

3. Fung, W., \& Hardcastle, J. M. (2000). Textiles in automotive engineering (Vol. 13). Woodhead Publishing.

4. Islam, S. (2008). Development of automotive textiles with antiodour/antimicrobial properties.

5. Kamath, M. G., Bhat, G. S., Parikh!, D. V., \& Mueller, D. (2005). Cotton fiber nonwovens for automotive composites. International Nonwovens Journal, 14 (1), 34-40.

6. Singha, K. (2012). Strategies for in automobile: strategies for using automotive textiles-manufacturing techniques and applications. Journal of Safety Engineering, 1(1), 7-16.

7. Mezarciöz, S., Mezarciöz, S., \& Oğulata, R. T. (2011). Teknik TekstillerOtobüs Koltuk Döşemelerinde Kullanimi Ve Uygulanan Test Yöntemleri. Journal of Textiles \& Engineers/Tekstil ve Mühendis, 18(83), 36-41.

8. De Vietro, N., Belforte, L., Lambertini, V., Placenza, B., \& Fracassi, F. (2015). Plasma treatment for preparing durable water repellent and antistain synthetic fabrics for automotive applications. Journal of Surface Engineered Materials and Advanced Technology, 5(03), 103. contributed to the effect of density properties on burning behavior of fabrics. It was indicated that fluoroalkyl acrylate copolymer provided excellent water repellent effect and good oil repellent effect on polyester fabrics while untreated samples did not show any water or oil repellent effect. Characterization tests were carried out, untreated and treated samples were compared to each other and finishing chemicals were indicated on the surface of the treated fabrics in SEM test whereas characteristic and functional chemical bond peaks were captured in FTIR-ATR analysis. It was considered that the recipes used in this study could serve as a model of finishing applications for improving multifunctional textile structures in automotive industry.

\section{Acknowledgement}

The author of this study is grateful to Birlik Yün İplik Company and Microscopy Laboratory of Department of Physics of Faculty of Arts and Science, Uludag University, for their kind support.
9. Haroglu, D., Powell, N., \& Seyam, A. F. M. (2017). A textile-based optical fiber sensor design for automotive seat occupancy sensing. The Journal of The Textile Institute, 108(1), 49-57.

10. Singha, K. (2012). A review on coating \& lamination in textiles: processes and applications. American Journal of Polymer Science, 2(3), $39-49$.

11. Kadem, F. D., \& Ergen, A. (2011). Investigation of some comfort properties of fabrics laminated with different types of membranes. Journal of Textile \& Apparel/Tekstil ve Konfeksiyon, 21(4),323-327.

12. Bulut, Y., \& Sülar, V. (2010). Kaplama veya laminasyon teknikleri ile üretilen kumaşlarin genel özellikleri ve performans testleri. Tekstil ve Mühendis, 15(71),6-16.

13. Schwarz, I. G., Kovačević, S., \& Kos, I. (2015). Physical-mechanical properties of automotive textile materials. Journal of Industrial Textiles, 45(3), 323-337.

14. Sen, A. K. (2001). Coated textiles: principles and applications. Crc Press.

15. Ekici, B., Kentli, A., \& Küçük, H. (2012). Improving sound absorption property of polyurethane foams by adding tea-leaf fibers. Archives of Acoustics, 37(4), 515-520.

16. Mukhopadhyay, S. K., \& Partridge, J. F. (1999). Automotive textiles Textile progress, 29(1-2), 1-125. 
17. Rajan, R., Rainosalo, E., Ramamoorthy, S. K., Thomas, S. P., Zavašnik J., Vuorinen, J., \& Skrifvars, M. (2018). Mechanical, thermal, and burning properties of viscose fabric composites: Influence of epoxy resin modification. Journal of Applied Polymer Science, 135(36), 46673.

18. https://www.uclan.ac.uk/about_us/facilities/assets/flammability_test_for_ motor_vehicle_interiors.pdf

19. Khoddami, A., Bazanjani, S., \& Gong, R. H. (2015). Investigating the effects of different repellent agents on the performance of nove polyester/wool blended fabrics. Journal of Engineered Fibers and Fabrics, 10(2), 137-146.

20. Schindler, W. D., \& Hauser, P. J. (2004). Chemical finishing of textiles. Elsevier.

21. Ömeroğullari, Z., \& Kut D. (2012). Flame Retardancy in Textile. Uludağ University Journal of The Faculty of Engineering, 17(1), 27-41.
22. Noor Z. A. A., \& Rahmah M. (2016). Calcium carbonate composition effect upon morphology, water absorption and flexural properties of hybrid filled kenaf and rice husk. International Journal of Advances in Science Engineering and Technology, 4(2), 31-35.

23. Ömeroğullari, Z., \& Kut, D. (2011). Investigation of burning behavior of polyester fabric with using natural structured flame retardant agent. Journal of Textile \& Apparel/Tekstil ve Konfeksiyon, 21(4),364-368.

24. Ömeroğulları Başyiğit, Z., \& Kut, D. (2018). Formaldehyde-free and halogen-free flame retardant finishing on cotton fabric. Journal of Textile \& Apparel/Tekstil ve Konfeksiyon, 28(4), 287-293.

25. Socrates, G. (2004). Infrared and Raman characteristic group frequencies: tables and charts. John Wiley \& Sons.

26. Al-Hosney, H. A., \& Grassian, V. H. (2005). Water, sulfur dioxide and nitric acid adsorption on calcium carbonate: A transmission and ATRFTIR study. Physical Chemistry Chemical Physics, 7(6), 1266-1276. 